\title{
BLENDED LEARNING A GYAKORLATBAN: A GAZDASÁGI SZIMULÁCIÓS JÁTÉK HATÁSA AZ ÉSZLELT TANULÁSRA
}

\author{
Aranyossy Márta - Kulcsár Eszter
}

Elemzésünk célja a szimulációk felsőoktatásban való felhasználása kapcsán annak a vizsgálata, hogy ez a módszer képes-e a tudástranszfert élvezetesebbé és hatékonyabbá tenni. Kérdőív segítségével mértük a diákok észlelt tanulási hatékonyságát, illetve, hogy mennyire élvezték a kurzusokat és kihívó feladatokat. Az adatok elemzésére leíró statisztika módszerek mellett PLS-útelemzést is alkalmaztunk. Eredményeink azt mutatták, hogy a kihívást jelentő, izgalmas és élményt adó szimulációs játék pozitív hatással van az észlelt tanulásra. Ugyanakkor csak a kihívó feladatok vagy a csupán izgalmas gyakorlatok nem érnek el szignifikáns hatást, amennyiben az élményfaktor hiányzik a szimulációs játék jellemzői közül.

JEL-kód: I21

Kulcsszavak: blended learning, digitális oktatás, gyakorlati tanulás, játékalapú tanulás, szimuláció

\section{BEVEZETÉS}

Az empirikus vizsgálatok azt mutatják, hogy a hagyományos tanulási módszerek, mint az előadás, olvasás, audiovizuális eszközök, de még a bemutatók is maximum 30\%-os tanulási hatékonyságot érnek el (1. 1. ábra, Motorola University, 1996). Ezzel szemben az interaktív módszerek, mint a csoportos megbeszélés, a gyakorlati tapasztalás és az egymás tanítása a 90\%-os hatékonyságot is elérhetik. Az utóbbi évtizedekben bekövetkező tanulási környezetváltozás is a gyakorlatorientáltabb módszerek irányába való elmozduláshoz vezetett. A hatvanas-hetvenes évektől kezdődően az információs és telekommunikációs technológiák fejlődése új lehetőségeket teremtett, egyre több atipikus tanulási forma vált elérhetővé. Ezen belül a távoktatás és az e-learning meghatározó irányvonalak lettek (Merkovity és Nemeslaki, 2014).

1 Aranyossy Márta egyetemi docens, Budapesti Corvinus Egyetem. E-mail: marta.aranyossy@unicorvinus.hu.

Kulcsár Eszter szenior HR-koordinátor, Európai Központi Bank. E-mail: kulcsareszter9o@gmail. com. 


\section{1. ábra}

\section{A tanulási piramis, az oktatási módszerek és azok hatékonysága}

MÓDSZER
Előadás
Olvasás
Audiovizuális
Demonstráció
Vitafórum
Gyakorlatvégzés
Egymás tanítása

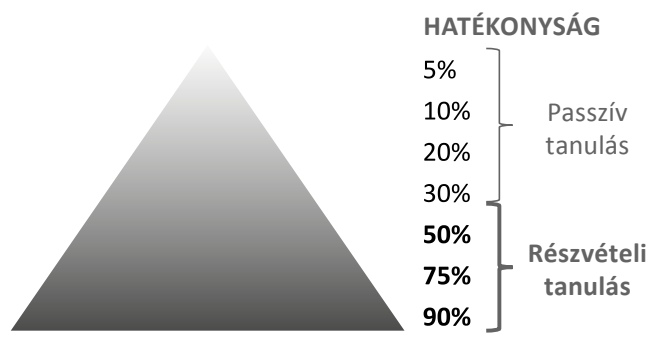

Forrás: Motorola University (1996) alapján saját szerkesztés

Tanulmányunk elsőként a blended learning, a játékosítás és szimulációk fogalmát járja körül, néhány kapcsolódó empirikus kutatási eredményt is összegezve. Majd bemutatjuk a kutatásunkat irányító, a szimulációk hatékonyságára vonatkozó kérdésünket, és azokat az modellezési, adatgyüjtési és elemzési módszereket, amelyek segítségével ezen kutatási kérdést körbejárni igyekeztünk. Végül részletesen elemezzük kutatásunk eredményeit és az abból levonható következtetéseket, majd a kutatás korlátainak és jövőbeli kiterjesztési lehetőségeinek bemutatásával zárjuk a tanulmányt.

\section{BLENDED LEARNING, JÁTÉKOSÍTÁS, SZIMULÁCIÓK - ALAPFOGALMAK ÉS IRODALMI ÉTTEKINTÉS}

\subsection{Blended learning}

Docsa Gergő és Szlávik Péter (2015) tanulmányukban három fö típust határozott meg az oktatási módok szétválasztásához: 1) hagyományos „face-to-face”, azaz személyes, jellemzően tantermi képzés, 2) „distributed”, vagyis a távoktatás, illetve 3) „blended learning”, azaz kombinált tanulás. A hagyományos oktatás, amikor az oktató és a diákok egy térben és időben találhatók, jelenleg a legelterjedtebb forma a világon. A távoktatás esetében sem térben, sem időben nem kell egy helyen lenniük a szereplőknek, a tudástranszfert az oktatási anyagok közvetítik a résztvevők felé. A harmadik típus pedig az előzőek keveréke, a blended learning, amely a hagyományos és a távoktatás során használt elemeket ötvözi.

A „The Handbook of Blended Learning” szerzői (Bonk és Graham, 2006) a következő definíciót használták: a blended learning rendszerek a személyes és a számítógép által közvetített instrukciókat kombinálják. Kicsit más megfogalmazásban 
- Greer, Rowland és Smith (2014), illetve Behjat, Yamini és Bagheri (2012) meghatározásai alapján - a blended learning egy olyan oktatási környezetet jelent, ahol a hallgatók a feladataik egy részét számítógépeken, más részét pedig hagyományos tantermi környezetben, tanáraikkal vagy társaikkal együtt végzik el. Mindezt többnyire információtechnológiai megoldások teszik lehetővé, a távoktatás formája gyakran e-learning (1. Forgó, 2009). A 2. ábra egy olyan szempontrendszert szemléltet, amelyen a dimenziók érvényesülését állítva kísérletezhető ki egy-egy újabb megoldás. Ezen dimenziók mentén a blended learning valahol a két véglet között helyezkedik el, és az alkalmazásának sajátosságaitól függően kerül közelebb vagy az egyik, vagy a másik módszertanhoz.

\section{2. ábra}

\section{A hagyományos és a távoktatást leíró négy dimenzió}

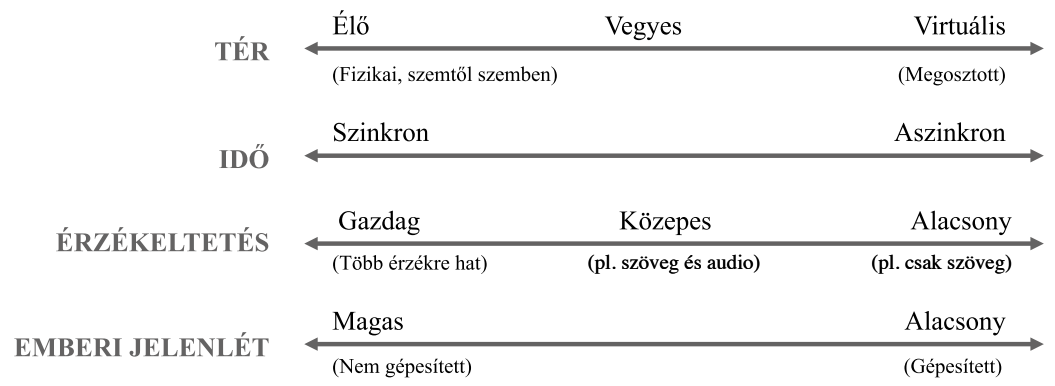

Forrás: Bonk és Graham (2006) alapján

Felmerülhet a kérdés, hogy miért akarják egyáltalán keverni a már meglévő, külön-külön is müködő módszereket. Osguthorpe és Graham (2003) szerint a legfontosabb motivációs erővel a pedagógiai fejlesztés, az elérhetőség és flexibilitás növelése, illetve a költséghatékonyság bírnak mint átfogó kategóriák. A jövőre vonatkozó várakozások pedig azt mutatják, hogy a blended learning lesz az oktatás általánosan elfogadott koncepciója, és egyre népszerübbé válik mind a felsőoktatásban (1. Garrison és Kanuka, 2004), mind a vállalati oktatás területén.

\subsection{A hallgatói igények változása}

A 20. század második felétől a digitális fejlődés üteme felgyorsult, az internet megjelenésével egy újabb, gyorsabb világ alakult ki. Sokan ezt tartják a harmadik ipari forradalomnak, ami az élet minden területére kihat, köztük az oktatásra is. A változások nemcsak az oktatási eszközöket, hanem a diákok igényeit is megváltoztatták. Marc Prensky (2001) a kétezres évek elején vizsgálta az amerikai diákok 
megváltozott igényeit. Ekkor mentek ugyanis iskolába azok a diákok, akik már a digitális világba születtek bele, és abban szocializálódtak. Ennek a generációnak a tagjai számítógépek, videójátékok, mobiltelefonok és egyéb digitális eszközök között nőttek fel. Ennek következtében megváltozott a gondolkodásmódjuk, és az eltérő gyerekkori élmények következtében az agyszerkezetük is módosult. Az új generáció tagjai már azt szokták meg, hogy gyorsan kapnak információt, a többfunkciós gondolkodásmódot és a vizualitást részesítik előnyben. Az információk random elérését és a csoportos gondolkodást preferálják. A gyors eredményeket és a gyakori jutalmazást kedvelik, inkább játszanának, mint tanulnának.

Kicsit késleltetve hazánkban is aktuális kérdéssé vált a digitalizálódás és annak az oktatási rendszerre, módszerekre gyakorolt hatása (l. például Csapó, 2002). Docsa és Szlávik (2015) cikkükben kiemelik, hogy a technológiai fejlődés hatására napjainkra egyre gyorsabban kerülnek piacra új digitális eszközök. Ennek hatására az oktatási intézményeknek az újdonságok adaptálására és versenyelőnnyé konvertálására jutó ideje annyira lecsökkent, hogy az új technológiák alkalmazása nem jelent többé előnyt, hanem alapkövetelménnyé vált a piaci verseny során. Mivel a hallgatókért is verseny folyik az egyetemen, így az ő megnyerésükhöz és megtartásukhoz is szükség van a technológiai újdonságok használatára. A szerzőpáros azt is kiemeli, hogy az új generációs hallgatóknak megváltoztak az igényei, így interaktív eszközöket kell bevetni a figyelmük elnyeréséért. A megoldást jelentő módszertani megközelítések közül a szerzők a csoportmunkát, a számítástechnikai laboratóriumokat, a játékokat és a szimulációkat emelik ki.

Ezek mind olyan eszközök, amelyek segítenek kialakítani a diákok elköteleződését a tanulás iránt, illetve a gyakorlati módszerek növelik a tanultak tudássá válásának hatékonyságát. A digitális megoldások segítenek a diákoknak a tananyag elérésében és megértésében, sok esetben a megtanulásában és a visszamérésében is. A blended learning megközelítés többnyire a hallgatótól is többet vár el: hogy kezébe vegye a tanulási folyamatot, felelősséget vállaljon érte és önmagát motiválja (Krishnan, 2016) Cserébe természetesen egyben nagyobb autonómiát és kontrollt is kínál a hallgatók számára a tanulási folyamat során (Tao, Cheng és Sun, 2009).

Az oktatóknak is előnyt jelentenek az új lehetőségek, ugyanakkor a tanóra szervezése nehezebbé válhat számukra. Lalima és Dangwal (2017) például kiemeli, hogy a sikeres blended learning alkalmazás alapfeltétele - a hozzáférhető technológiai és a folyamatos internetelérés mellett - a jól képzett és tudományos attitűddel rendelkező oktató, aki nyitott a változásra. Az elmélet gyakorlatba ültetése hosszabb folyamattá alakulhat, hiszen több feladatra különböző módokon kell felkészülnie. Az erőfeszítés azonban megéri a fáradtságot, hiszen az így kialakított blended learning módszerek hatékonysága jóval túlszárnyalja a hagyományos oktatásét (Docsa és Szlávik, 2015). 


\subsection{Szimuláció és játékosítás}

Mindezen trendekbe illeszkedően elterjedtebb tanulási-tanítási megközelítés a játékosítás és a szimulációk alkalmazása is. A játék kifejezés e helyütt a szabályok által körülhatárolt, meghatározott célok elérésére irányuló, versenyszerü küzdelmet jelöli (Deterding, Dixon, Khaled és Nacke, 2011) mesterséges környezetben de a játékosítás során valós célok érdekében.

Ettől eltérő, de ezzel gyakran összekapcsolódó trend a szimulációk elterjedése. A szimulációk a valóság olyan egyszerüsített leképezései, amelyek rendszerszemléletben, bizonyos változókat és az azok közötti dinamikus kapcsolatokat modelleznek (Sauve, Renaud, Kaufman és Marquis, 2007). A szimulációk oktatási alkalmazása jól illeszkedik a Carl Rogers (1969) és később Kolb (1984) nevéhez köthető tapasztalati tanulási megközelítésbe.

Az utóbbi években egyre több szerző hangsúlyozza a szimulációs játékok oktatási elönyeit a szakirodalomban (Geithner és Menzel, 2016; Ranchhod, Gurău, Loukis és Trivedi, 2014), kiemelve a pozitív motivációs hatásait és tanulóközpontú képességfejlesztő hatásait. Ezen alkalmazások egyesítik a játékosítás szórakoztató jellegének előnyeit a szimulációk gyakorlatiasságát, megtörve ezzel a hagyományos tantermi képzések monotóniáját (Matute és Melero, 2016). Matute és Melero (2016) egyetemi szimulációs játékokra vonatkozó kutatása kimutatta, hogy azt a hallgatók szórakoztatónak találják, és olyan pozitív érzelmi állapotokat társítanak hozzá, mint a lelkesedés vagy a flow-élmény - és mindemellett hasznosnak is tartották. Ranchhod és szerzőtársai (2014) kutatásukban a szimulációs játékok négy értékes hatását vizsgálták (élményteremtés, fogalmi megértés, képességfejlesztés, hatásos értékelés), és arra jutottak, hogy az élménygenerálás szignifikáns hatással van a fogalmi megértésre, és mindkettő hat a képességfejlesztésre.

\section{KUTATÁSI KÉRDÉS, MODELL ÉS MÓDSZERTAN}

Alapvető kérdés, hogy a diákoknak kell-e elfogadniuk a meglévő módszereket, vagy az oktatóknak kell alkalmazkodniuk a diákok megváltozott igényeihez. Úgy véljük, hogy az oktatás célja a tudás átadása, és egy jó oktató arra törekszik, hogy ezt minél sikeresebben tehesse meg. Ehhez tudnia kell, hogy a diákjait hogyan képes motiválni, és annak alapján választja ki a megfelelő oktatási eszközt. Az $\mathrm{X}, \mathrm{Y}$ és $\mathrm{Z}$ generációk már a digitális világ szülöttei, így számukra ismeretlen a digitális eszközöket nélkülöző világ. Az utóbbi évtized szakirodalma ezért különösen hangsúlyozza a játékos megoldásokat alkalmazó blended learning előnyeit. A játszva tanulás szórakoztatóbb, kellemesebb lehet, miközben a diákok gyakorlati, tapasztalati tudásra tehetnek szert, hatékonyabb tudástranszferrel. 
Kutatásunkban azt vizsgáljuk, hogy ezek a szakirodalomban megjelenő, pozitív hatások kimutathatók-e empirikus jelleggel, hazai mintán. Vizsgálatunk fókuszát blended learning konstrukcióban megvalósuló gazdasági felsőoktatási szimulációs játékok képezték. Kérdésünk tehát: az online szimulációs játék pozitív hatással van-e az egyetemi gazdasági képzésben résztvevők észlelt tanulására?

A kutatási kérdés vizsgálatához Hamari és szerzőtársai (2016) játék alapú tanulást vizsgáló modelljét vettük alapul. A szerzők feltételezése itt az volt, hogy a flowélmény (összetevői: a kihívás és a képesség), a játék iránti elkötelezettség, illetve a bevonódás pozitívan hat az észlelt tanulásra (1. 3. ábra). Az ő kutatásukban 134 középiskolai diák és 40 alapképzésben részt vevő gépészhallgató vett részt az Egyesült Államokban egy, a képzésük során használt, játékosított megoldás kapcsán kitöltött, 19 kérdésből álló kérdőív segítségével. Az eredményeik azt mutatták, hogy mind a képesség, mind a kihívás és az elkötelezettség pozitív hatással van az észlelt tanulásra. A kutatás fő eredménye azt mutatta, hogy a vizsgált játékok alkalmazása hatékony kiegészítője volt az oktatásnak, mivel növelte a diákok elkötelezettségét, amit tovább erősítettek a kihívó feladatok és a hallgatók képességeinek feszegetése.

\section{3. ábra}

\section{Hamari és szerzőtársai (2016) kutatási modellje}

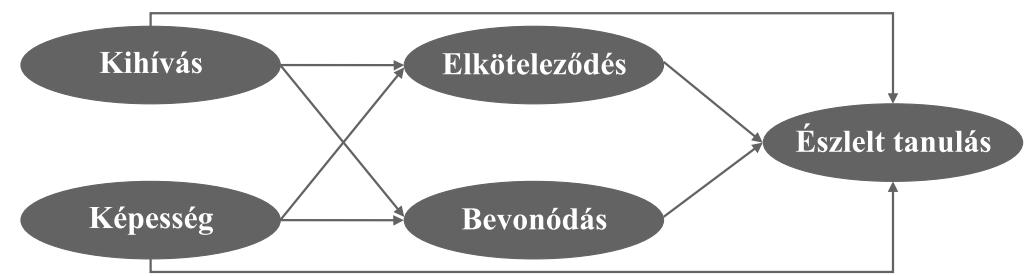

Forrás: Hamari és szerzőtársai (2016:174)

Hamari és szerzőtársai (2016) kutatásának modelljét és validált kérdőívét is felhasználtuk a jelen kutatás megtervezése során. A kérdőíves adatgyüjtésünk során hasonló zárt, 10 fokozatú Likert-skálán mért kérdéseket tettünk fel a kutatásban részt vevő hallgatóknak. Az 1 válaszérték azt jelentette, hogy a válaszadó egyáltalán nem ért egyet a megfogalmazott állítással, és a 10 jelentette a teljes mértékü egyetértést. A 10 fokozatú skála biztosította, hogy a válaszadóknak mindenképpen állást kelljen foglalniuk abban, hogy inkább egyetértenek a kérdéssel, vagy inkább nem értenek egyet azzal. Összesen 19 kérdésből állt a kérdőív, amelyből 2 kérdés fordított kódolású. ${ }^{2}$

2 A kérdőívben a két fordított kódolású kérdést (10. és 11. kérdés) az adatfelvétel után átkódoltuk. Az eredeti 1-es érték 10-es értéknek felel meg, a 2-es 9-nek és így tovább. 
Empirikus vizsgálatunk tárgya a SimTeam Training Kft. megegyező nevü szoftvere mint játékosított oktatási eszköz (serious game) volt. A SimTeam egy online működő, üzleti szimulációs szoftver, amely egy projektalapon müködő vállalati környezetet modellez. A résztvevők 4 fös csapatokban virtuális vállalatokat irányítanak, amelyek azonos piacon müködnek, és egymással versenyeznek az ügyfélprojektekért, valamint az azokat elvégezni képes munkavállalókért. A csapattagok 4 szerepkört töltenek be (Vezérigazgató, Kereskedelmi igazgató, HRigazgató és Pénzügyi igazgató), és ezzel alkotják a modellvállalat felsővezetését. A szimuláció tartalmaz puha és kemény szabályokat, ezeknek a betartásával vagy be nem tartásával a modellvállalatot irányító csapat befolyásolni tudja a projektek sikerességét és a vállalat eredményességét.

A SimTeam-szimulációt partnerei annak érdekében használják, hogy hatékonyabb tudástranszfert érjenek el, és élményalapú tanulást nyújtsanak a menedzsmenttréning-programjaik résztvevőinek. Egyetemekkel, egyetemi oktatókkal is kapcsolatban áll a cég, így a SimTeam-szimulációt a Budapesti Corvinus Egyetemen és a Budapesti Gazdasági Egyetemen is használják. A kutatás során felkerestük azt a négy egyetemi oktatót, akik kurzusaik során a SimTeam szimulációs szoftvert használták. ${ }^{3}$ Ezen kurzusok során üzleti gazdaságtanról, személyügyi kontrollingról és vállalkozási ismeretekről tanultak a hallgatók. A tanárok az elméleti előadást követően a szemináriumokon használták a szimulációt annak érdekében, hogy a diákok a gyakorlatban is megtapasztalhassák azt, aminek az elméleti hátterével korábban már megismerkedtek. Az oktatók beleegyezésével és közremüködésével a kérdőívet minden, a kurzuson részt vett hallgatóhoz eljuttattuk a 2015/16-os tanév végén. A kutatás során 111 hallgató töltötte ki a kérdőívet, amely a 162 fős teljes populációnak 69\%-át teszi ki (1. 1. táblázat).

\section{1. táblázat}

A kutatásban részt vevő egyetemi csoportok és a minta összetétele

\begin{tabular}{lcccccc}
\hline Csoportok: & A & B & C & D & E & Összesen \\
\hline $\begin{array}{l}\text { Kurzuson részt } \\
\text { vett hallgatók }\end{array}$ & 29 & 62 & 29 & 20 & 22 & $\mathbf{1 6 2}$ \\
$\begin{array}{l}\text { száma } \\
\text { Kitöltők száma }\end{array}$ & 15 & 37 & 29 & 12 & 18 & $\mathbf{1 1 1}$ \\
Kitöltők aránya & $51,74 \%$ & $59,68 \%$ & $100 \%$ & $60 \%$ & $81,82 \%$ & $\mathbf{6 8 , 5 2 \%}$ \\
Kitöltés nyelve & $\begin{array}{c}\text { magyar } \\
\text { magyar }\end{array}$ & $\begin{array}{c}\text { magyar } \\
\text { online }\end{array}$ & $\begin{array}{c}\text { angol } \\
\text { paṕralapú }\end{array}$ & $\begin{array}{c}\text { online } \\
\text { magyar }\end{array}$ & papíralapú & \\
\hline
\end{tabular}

Forrás: saját számítás

3 E helyütt szeretnénk köszönetet mondani a kutatást lehetővé tevő oktatóknak, különösen $D r$. Boda Györgynek, Dr. Matyusz Zsoltnak, Dr. Stocker Miklósnak és Dr. Petheő Attilának. 
Az értékeléshez - a leíró statisztikai módszereken túl - PLS (Partial least squares) elemzést alkalmaztunk. A PLS egy SEM (Structural Equation Modelling) technika, amely egyszerre teszi lehetővé a strukturális modell (a látens változók közötti összefüggésháló) és a mérési modell becslését (amely a látens változókat a megfigyelési változókból előállítja), iteratív módon, maximalizálva a varianciát. A PLS - más SEM-technikákhoz képest - kiküszöböli például a faktor meghatározatlanságának problémáját, és minimális elvárásokat támaszt a mérési skálák, a mintanagyság és eloszlás tekintetében (Chin, 1998:295). Ez a módszertani választás lehetővé tette azt is, hogy összevessük a magyar kutatási eredményeinket a Hamari és szerzőtársai (2016) kutatásában szereplő eredményekkel, illetve önálló modellt is építsünk.

\section{EREDMÉNYEK}

\subsection{Leíró statisztikák}

A 2. táblázat szemlélteti a kérdőív kérdéseire adott válaszok általános jellemzőit. A táblázatban kiemeltük az 5-nél alacsonyabb átlagot és mediánt, az 1, 2 vagy 10 értékű móduszt, variancia esetén az 5-nél nagyobb eseteket, illetve a legkisebb terjedelmet és a legnagyobb minimumokat, valamint a ferdeségnél jeleztük annak irányát is. A táblázatból kiderül, hogy minden kérdés esetében 111 érvényes adat volt elérhető, ami azt jelenti, hogy mindenki, aki kitöltötte a kérdőívet, minden egyes kérdésre válaszolt, tehát nem volt hiányzó adat.

A kérdőívre érkezett, összesített válaszok esetében az átlag, módusz és medián a legtöbb esetben együtt mozog, és hasonló értékeket mutat. Ez alól kivétel a 4., 16., 17. és 18. kérdés, ahol az eredmények azt mutatják, hogy válaszadóknak vegyes véleménye volt az adott kérdésekben (koncentráció nehézsége, határok feszegetése, saját teljesítmény és jártasság megítélése), azonban a móduszokból az derül ki, hogy ezekkel a kérdésekkel a legtöbben mégsem értettek egyet. A magas varianciaérték (az előbbieken túl a megértéstámogatás vagy a más tevékenység preferálása esetében) is a vélemények különbözőségét emeli ki, míg az alacsony terjedelem (V6-9, tehát az élvezetességre vonatkozó kérdések esetében) azt mutatja, hogy az adott kérdésekben viszonylag egyhangú véleménnyel rendelkeztek a hallgatók. A válaszok ferdesége is azt mutatja, hogy a legtöbben úgy érezték: valóban tanultak, a játék segített összpontosítani a figyelmüket, az órát szórakoztatónak és élvezetesnek találták, így nem is unatkoztak és nem is kívántak mással foglalkozni; a válaszadóknak valóban nem esett nehezére a koncentráció, és nem értenek egyet azzal, hogy ne lettek volna jók a játékban. 


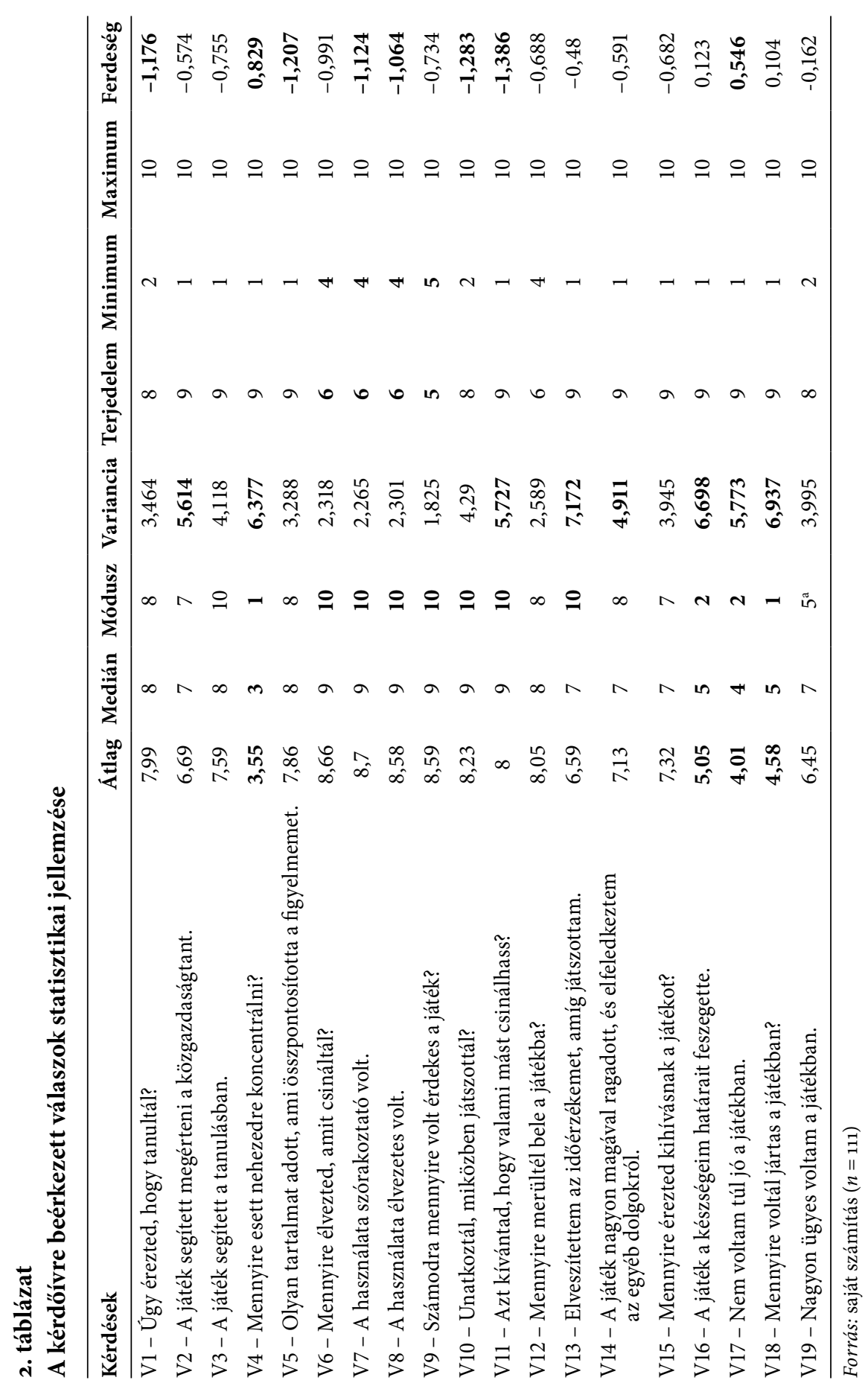




\section{2. Útelemzés összehasonlító szemléletben}

A saját adataink elemzését a továbbiakban SmartPLS 3 program segítségével végeztük el, amely kifejezetten a PLS-SEM alkalmazására lett kialakítva. A minta elemszámára különböző hüvelykujjszabályok léteznek, mi a 10-es szabályt (Hair, Hult, Ringle, Christian és Sarstedt, 2017:24) alkalmaztuk, amely szerint a modell változóinak tízszerese a minimális mintaelemszám. Ennek a feltételnek a modellünk és mintánk nagysága megfelel.

A 4. ábra a Hamari és szerzőtársai (2016) kutatás mintáján felépített PLS-modellt mutatja be. A strukturális modellt alkotó látens változók (ellipszisek) mellett bemutatja az azokhoz kapcsolódó indikátorokat (téglalapok; $\mathrm{V}_{1}-\mathrm{V}_{19}$, 1. részletesen 2. táblázat), a kapcsolat irányát, valamint a PLS-modellezés eredményét is. A strukturális modellben a standardizált útegyütthatók szerepelnek a nyilakon, az $\mathrm{R}^{2}$ értéke pedig a látens változók ellipszisében található.

\section{4. ábra}

Útelemzés eredménye Hamari és szerzőtársai (2016) modellje alapján, saját adatokkal tesztelve a kapcsolatokat

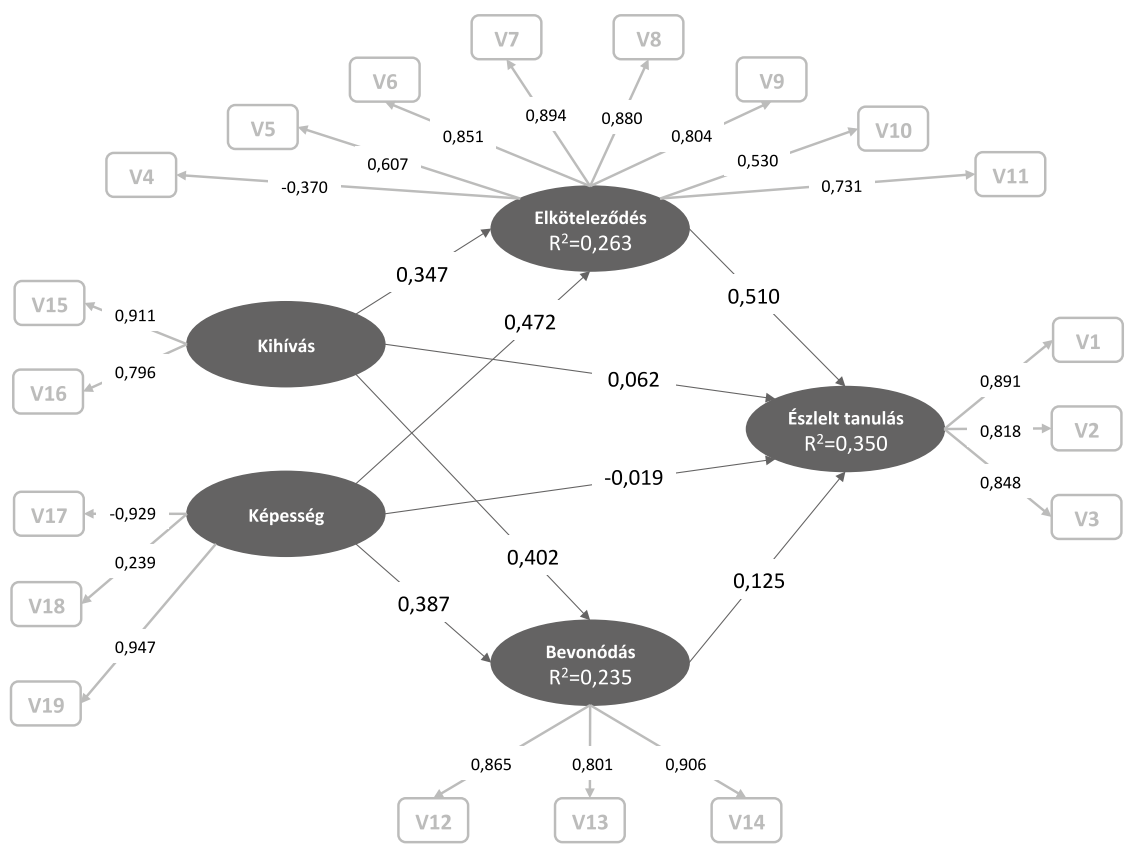

Forrás: saját számítás 
A látens változók megbízhatóságát és érvényességét vizsgáló tesztek alapján a Képesség látens változó összetétele nem megfelelő, míg a Kihívás és a Képesség esetében a küszöbérték alatti Cronbach-féle $\alpha$-mutató azt jelzi, hogy a látens változókhoz tartozó indikátorok nem egyformán megbízhatóak, továbbá a faktorterhelés esetén is 5 indikátor az általánosan elfogadott küszöbérték alatt teljesített. Ez tehát arra utal, hogy a Hamari-kutatásból átvett kérdések magyar nyelvre átültetve nem voltak közvetlenül alkalmasak az általuk elöre kijelölt komplex faktorok hazai mérésére, illetve a kérdések közötti összefüggés más mintát mutat. Azt is meg kell említenünk, hogy az indikátorok faktorterhelését összehasonlítva a Hamari és szerzőtársai (2016) vizsgálattal, az ő esetükben csupán három változóhoz tartozó érték kisebb, mint 0,7. A teszt alapján a modellben multikollinearitás nem állt fenn.

Az útegyütthatók szignifikanciájának vizsgálatához bootstrapping-eljárást használtunk, amelyhez 5\%-os szignifikanciaszintet és kétoldali próbát alkalmaztunk. A direkt és indirekt hatások vizsgálata során kiderült, hogy az Elköteleződésnek volt a legnagyobb hatása az Észlelt tanulásra, majd ezt követte a Kihívás, a Képesség és a Bevonódás - azonban ezek közül csak az első kettő szignifikáns. A Kihívás mind az Elköteleződésen $\left(\beta=0,347^{\star}\right)$, mind a Bevonódáson $\left(\beta=0,402^{\star}\right)$ keresztül közvetetten is érzékeltette a hatását a tanulásra, és az indirekt hatás magasabb volt, mint a direkt hatás.

Összehasonlításképpen: Hamari és szerzőtársai (2016) eredményei alapján a Kihívásnak volt a legnagyobb hatása az Észlelt tanulásra $(\beta=0,695)$, majd ezt követte az Elköteleződés $(\beta=0,474)$, a Képesség $(\beta=0,209)$ és a Bevonódás $(\beta=0,084)$. Ebből az összehasonlításból és a látens változók determinációs együtthatójának $\left(\mathrm{R}^{2}\right)$ vizsgálatából az derült ki, hogy a modell magyar mintán való ismételt vizsgálata során a látens változók magyarázó ereje minden esetben alacsonyabb volt. A kutatásban szereplők kulturális különbségeiből is fakadhat, hogy az USA-ban vizsgált diákok esetében a Kihívásnak volt a legnagyobb szerepe az Észlelt tanulás befolyásolásában, míg a magyaroknál az Elköteleződésnek - de lehetséges, hogy a faktorelemzés illeszkedése kapcsán már bemutatott mérési elégtelenségekre vezethető vissza a eredménykülönbség egy része. 


\subsection{A saját PLS-modell eredményei}

Mindezek alapján a Hamari-vizsgálat rekonstruálása után objektív többváltozós statisztikai módszerekkel saját modellt építettünk a magyar mintánkon. A látens változók kialakításához a faktorelemzést, azon belül pedig főkomponens-elemző eljárást használtunk. ${ }^{4} \mathrm{~A}$ faktoranalízis esetében is ugyanazt az adatbázist használtuk, mint korábban, így azt hiányzó és kiugró adat nem rontotta. Azt feltételeztük, hogy a korábban alkalmazott látens változók száma nem fog változni, és varimax-rotálást alkalmaztunk. Az elemzéshez a Kaiser-kritériumot használtuk, és végül 5 olyan változónk lett, ami teljesíti az egynél nagyobb sajátérték-kritériumot. Ez az öt faktor a teljes variancia $70 \%$-át magyarázza, ami meghaladja a 60\%os küszöbértéket. Eredményeink mind a KMO-5, mind a Bartlett-teszt ${ }^{6}$ kapcsán kielégítőek.

Az eredményeket a következő két táblázat szemlélteti. A 3. táblázat a magyar minta megfelelöségét mutatja, míg a 4. táblázat összehasonlítja a Hamari és szerzőtársai (2016) modell faktorait (fejléc) és a hozzájuk tartozó változókat (kérdések sorszámai) a magyar modell látens változóinak összetételével.

\section{3. táblázat}

A magyar minta megfelelőségének és a változók függetlenségének tesztelése

\begin{tabular}{lcc}
\hline Kaiser-Meyer-Olkin-mutató &, 822 \\
\hline & khi-négyzet & 1182,414 \\
Bartlett-teszt & df & 171 \\
& szig. &, 000 \\
\hline
\end{tabular}

Forrás: saját számítás

4 A faktorelemzés esetében több hüvelykujjszabály létezik a minimális elemszámra vonatkozóan, ezek közül a Kovács Erzsébet által javasolt $n \geq 5 p$ szabályt alkalmaztuk, ahol $n$ a megfigyelések száma és p a változók száma (Kovács, 2011:89). Ennek alapján az általunk gyűjtött 111 megfigyelés valóban meghaladja a minimális követelményt, az $5 \times 19$, azaz 95 elemet.

5 A Kaiser-Meyer-Olkin-kritérium (KMO) az egyik leggyakrabban használt mérőszám arra vonatkozóan, hogy a vizsgált változók mennyire alkalmasak a faktoranalízisre (CERNY és KAISER, 1977). A o,8 feletti KMO-érték nagyon jó alkalmasságot jelez.

6 A Bartlett-teszt azt vizsgálja, hogy a változók korrelálatlanok-e (SNEDECor és CocHRAN, 1989) A faktorelemzés feltétele, hogy a változók között legyen korreláció. 


\section{4. táblázat}

A Hamari és szerzőtársai (2016)

és a magyar modell látens változóinak összetétele, összehasonlítása azaz melyik kérdést (V1-V19) melyik faktor tartalmazza

\begin{tabular}{|c|c|c|c|c|c|c|c|c|c|}
\hline \multicolumn{5}{|c|}{ Hamari és szerzőtársai (2016) besorolás } & \multicolumn{5}{|c|}{ Faktor analízis alapján } \\
\hline & 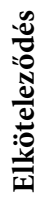 & 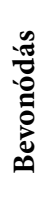 & $\underset{Z}{\stackrel{Z}{Z}}$ & 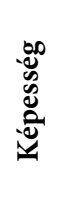 & & 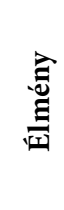 & 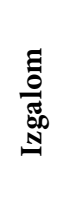 & 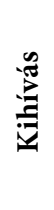 & 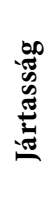 \\
\hline 1 & 4 & 12 & 15 & 17 & 1 & 6 & 4 & 15 & 18 \\
\hline 2 & 5 & 13 & 16 & 18 & 2 & 7 & 10 & 16 & \\
\hline \multirow[t]{6}{*}{3} & 6 & 14 & & 19 & 3 & 8 & 11 & 17 & \\
\hline & 7 & & & & 5 & 9 & & 19 & \\
\hline & 8 & & & & & 12 & & & \\
\hline & 9 & & & & & 13 & & & \\
\hline & 10 & & & & & 14 & & & \\
\hline & 11 & & & & & & & & \\
\hline
\end{tabular}

Forrás: saját számítás

A 4. táblázatból látszik, hogy az eredményeink az amerikai kutatáshoz hasonlóak, néhány változó azonban másik faktorba került. Mivel a saját elemzésünk során kapott új faktorok összetétele megváltozott, így a látens változók új összefoglaló nevet kaptak, ezek: Tanulás, Élmény, Izgalom, Kihívás és Jártasság. A Jártasság látens változó semelyik másik látens változóra sem gyakorolt szignifikáns hatást, és mivel az egy indikátorral jellemzett látens változó nem javasolt 50-nél nagyobb mintaelemszám esetén (Hair és szerzőtársai, 2017), ezért úgy döntöttünk, hogy ezt a változót (és az ezzel megegyező indikátort is) kivesszük a modellből.

A formatív mérési modellek esetében a multikollinearitás vizsgálatából kiderült, hogy a V7 és a V8 VIF-értékei meghaladják az 5-ös küszöbértéket. Ez érthető, hiszen az egyik kérdés a játék élvezetességét, míg a másik a játék szórakoztató voltát vizsgálja. Mivel a V8 indikátornak valamivel magasabb volt a faktorterhelési értéke, így ezt tartottuk meg és a V7-et kivettük a modellből. Hasonlóképpen ki kellett hagynunk a modellből a V16 indikátort is, mert a modellben nem bizonyult szignifikánsnak. Az Izgalomhoz kapcsolódó további feltételezésünk az volt, hogy nem csak a Tanulásra lesz hatással, hanem az Élményre is. Az így kialakult modell (1. 5. ábra) tesztelését PLS-algoritmus és a bootstrapping-eljárás lefuttatásával kezdtük. 


\section{5. ábra}

\section{A PLS-SEM eredményei a kialakított új modellben}

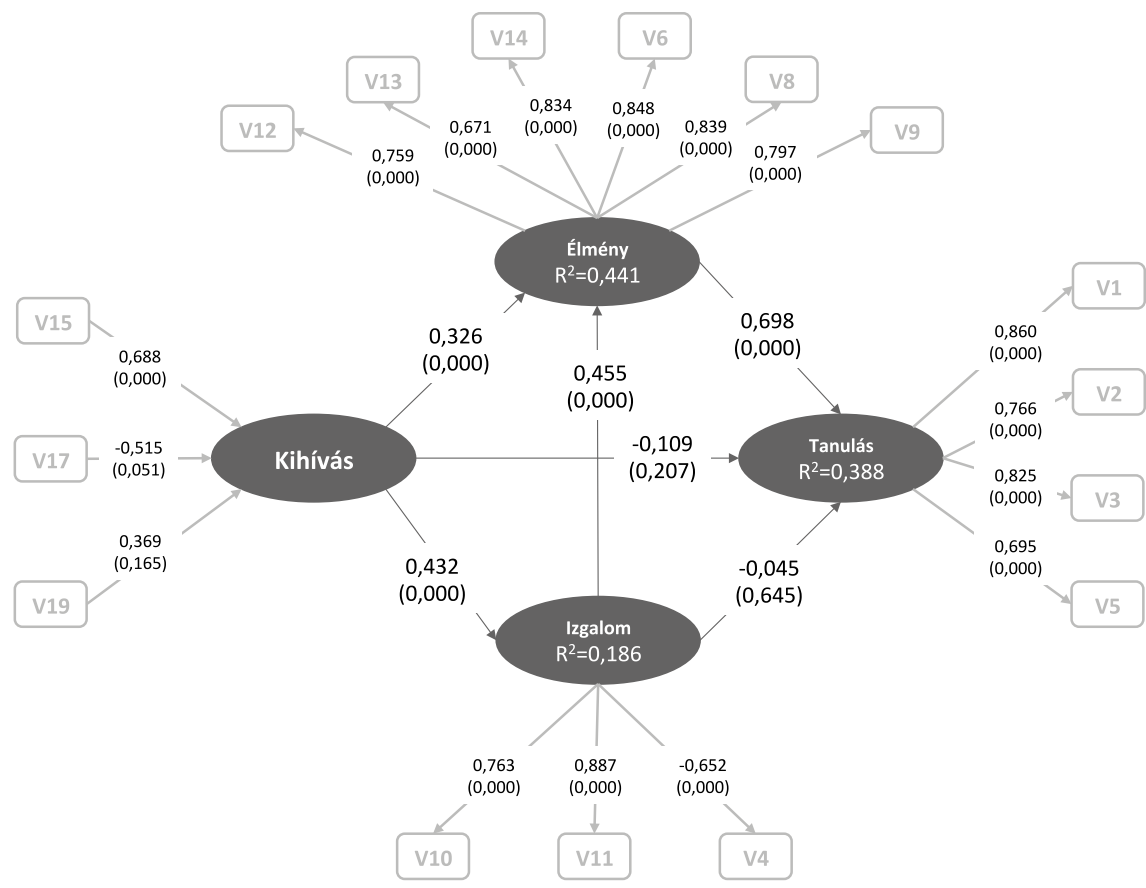

Forrás: saját számítás

A reflektív mérési modell értékeléséhez szükséges mutatókat az 5. táblázat összesíti. A Fornell-Larcker-kritérium minden esetben teljesül, hiszen mind a három reflektív látens változó AVE-értéke elfogadható. Az indikátorok faktorterhelése esetében a Tanulás és az Élmény esetében is van egy-egy o,7 alatti érték, azonban azok is nagyon közel állnak ehhez az elfogadási értékhez.

7 Az Izgalomhoz tartozó Cronbach-féle $\alpha$-mutató azt jelzi, hogy az indikátoroknak nem egyforma a megbízhatósága, míg a CR-mutató az összetétel bizonytalanságára hívja fel a figyelmet. Ennek a $\mathrm{V}_{4}$ indikátor az oka, melynek faktorterhelési értéke -0,625, azonban ezt eltávolítva sem éri el a Cronbach-féle $\alpha$-mutató a küszöbértéket, így a változót benne hagytuk a modellben. 


\section{5. táblázat}

A látens változók megbízhatósága és érvényessége, valamint a Fornell-Larcker-kritérium az új modellben

\begin{tabular}{lccccccc}
\hline & \multicolumn{2}{c}{$\begin{array}{c}\text { A változók megbízhatósága } \\
\text { és érvényessége }\end{array}$} & \multicolumn{5}{c}{$\begin{array}{c}\text { Fornell-Larcker- } \\
\text { kritérium }\end{array}$} \\
\hline & $\begin{array}{c}\text { Cronbach-féle } \\
\text { a-mutató }\end{array}$ & CR & AVE & Izgalom & Kihívás & Tanulás & Élmény \\
\hline Izgalom & $-0,448$ & 0,452 & 0,598 & 0,773 & & & \\
Kihívás & & & & 0,432 & & & \\
Tanulás & 0,800 & 0,868 & 0,622 & 0,323 & 0,236 & 0,789 & \\
Élmény & 0,887 & 0,914 & 0,639 & 0,596 & 0,522 & 0,614 & 0,800 \\
\hline
\end{tabular}

Forrás: saját számítás

A formatív mérési modell esetében a multikollinearitás már nem áll fenn, mivel a 7. változót kivettük a modellből. Végül a strukturális modell vizsgálatánál megállapítható, hogy a modellben nincsen multikollinearitás, és az útegyütthatók javarészt szignifikánsak. A hatásokat - amelyeket az 5. ábra is szemléltet - a 6. táblázat foglalja össze.

6. táblázat

Direkt, indirekt és teljes hatások az új modellben $\left({ }^{*}: \mathrm{p}<0,05\right)$

\begin{tabular}{lcccccc}
\hline Vizsgált hatás & \multicolumn{2}{c}{ Direkt hatás } & \multicolumn{2}{c}{ Indirekt hatás } & \multicolumn{2}{c}{ Teljes hatás } \\
\hline \multicolumn{1}{c}{$\ldots \rightarrow$ Tanulás } & $\boldsymbol{\beta}$ & $\mathbf{p}$ & $\boldsymbol{\beta}$ & $\mathbf{p}$ & $\boldsymbol{\beta}$ & $\mathbf{p}$ \\
\hline Izgalom & $-0,045$ & 0,645 & $\mathbf{0 , 3 1 8 ^ { \star }}$ & 0,000 & $\mathbf{0 , 2 7 3}^{\star}$ & 0,012 \\
Kihívás & $-0,109$ & 0,207 & $\mathbf{0 , 3 4 5 ^ { * }}$ & 0,000 & $\mathbf{0 , 2 3 6}^{*}$ & 0,014 \\
Élmény & $\mathbf{0 , 6 9 8}^{*}$ & 0,000 & - & - & $\mathbf{0 , 6 9 8}^{\star}$ & 0,000 \\
\hline
\end{tabular}

Forrás: saját számítás

A modellben a Tanulásra az Élménynek van a legnagyobb szignifikáns hatása, majd ezt követi az Izgalom és a Kihívás. Érdekes, hogy az Izgalomnak és a Kihívásnak a Tanulásra kifejtett direkt hatása mindkét esetben negatív, bár ezek nem szignifikáns értékek, vagyis a hatás a nulla körül mozog. Ez viszont azt jelenti, hogy az indirekt hatásuk volt erős, ahogy azt a táblázat is mutatja. Érdekes továbbá az is, hogy a Kihívásnak szignifikáns hatása van az Izgalomra, de mivel az Izgalomnak nincsen szignifikáns direkt hatása a Tanulásra, ezért minden Kihívásból eredő hatás az Élményen keresztül hat a Tanulásra. Tehát az Élményt közvetlenül és közvetetten is pozitívan befolyásolja a Kihívás. 
A modellben a látens változók magyarázó képességét tekintve az Élménynek a legmagasabb az $\mathrm{R}^{2}$ értéke (44,1\%), ezt követi a Tanulás 38,8\%-os és az Izgalom 18,6\%-os értéke.

\section{KÖVETKEZTETÉSEK}

Kutatásunkban 111 olyan hallgató vett részt, akik a gazdálkodástudományi tanulmányaik során online üzleti szimulációs szoftvert használták. Az adatok elsődleges elemzése és a kontrollkérdések egyaránt alátámasztották, hogy a hallgatók valóban élvezetesnek és izgalmasnak találták a szimulációval kiegészített órákat. A legtöbben azt válaszolták, hogy a játék segített nekik megérteni a tananyagot, és segített a tanulásban, ezért valóban úgy gondolják, hogy tanultak a kurzusok során. Ez természetesen nem csak a szimulációs program használatának köszönhető, hiszen az önmagában mit sem ér az oktató szakértelme nélkül. Az összességében tapasztalt pozitív tanulási hatékonysági és élményhatás egybecseng a bemutatott nemzetközi és hazai tapasztalatokkal (Pásztor, 2014) egyaránt.

A játék hatékonyan bevonta a hallgatókat, és a legtöbbjük számára kihívást jelentett a jó teljesítmény nyújtása. Összességében nem érezték úgy, hogy nagyon ügyesek lettek volna a játék során, de azért inkább egyetértettek az állítással. Ez természetesen összefügg azzal is, hogy nem voltak jártasak a játékban, hiszen nem volt előzetes tapasztalatuk a szimulációval kapcsolatban.

A PLS-útelemzés során a vizsgált kihívásra, élményekre és tanulásra vonatkozó kérdéseket mind Hamari és szerzőtársai (2016) modellje alapján, mind a saját mintánkra illeszkedő PLS-modellben megvizsgáltuk.

A saját kérdőíves eredményeinket a Hamari-modellbe illesztve az derült ki, hogy a diákok szemében az elköteleződésnek és a kihívásnak volt a legnagyobb hatása az észlelt tanulásra, a képességnek és a bevonódásnak pedig nem volt szignifikáns hatása. Ez összecseng az amerikai diákok körében végzett eredeti kutatással, az ő esetükben azonban a kihívás bizonyult erősebbnek, az elköteleződés pedig a második helyre került a hatások vizsgálatánál. Figyelembe véve azt a hatást, hogy az elsajátítási motiváció akkor működik jól, ha a cél optimális kihívó erővel bír (Józsa, 200o), ez a kimutatott hatás tanulságos lehet mind a nemzetközi szimulációtervezés, mind például az amerikai szimulációs játékok hazai alkalmazása során: hiszen lehetséges például, hogy a kihívás jellegét egy kicsit alacsonyabbra érdemes állítani a magyar hallgatók esetében.

Az új magyar modell eredményeinek értékeléséből az derült ki, hogy a kihívásnak és az izgalomnak is csak az indirekt hatása volt szignifikáns a tanulásra nézve. Mindkét látens változó az élményen keresztül fejtette ki hatását, aminek viszont közvetlen és jelentős hatása volt a tanulásra nézve. Összességében tehát azt lehet 
megállapítani, hogy egy olyan szimulációs játéknak, amely kihívást jelent és izgalmas, és ezáltal (is) élményt nyújt a hallgatók számára, annak pozitív hatása van az észlelt tanulásukra vonatkozóan. Ugyanakkor csak a kihívó feladatok vagy a csupán izgalmas gyakorlatok nem érnek el szignifikáns hatást, amennyiben az élményfaktor hiányzik a szimulációs játék jellemzői közül, hiszen ennek van a leginkább jótékony hatása a tanulásra; annak minden egyéb jellemző hatását ez közvetíti, szüri át.

\section{MÓDSZERTANI KORLÁTOK ÉS TOVÁBBI KUTATÁSI IRÁNYOK}

Természetesen a bemutatott empirikus kutatási eredmények csak bizonyos korlátok között értelmezhetők. A kérdőíves adatfelvétel vázát Hamari és szerzőtársai (2016) kutatása jelentette - az általuk validált kérdőív már bevált alapot jelentett, bár az egy csoportba tartozó kérdések egymást követően szerepeltek, ami esetleg befolyásolhatta a kitöltőket. Emellett megjegyzendő, hogy az alkalmazott Likert-skála a szakmai megítélés szerint átmenetet képez az ordinális és az intervallumskála között, ami szintén figyelembe veendő a módszertan-választásunk tükrében. Az elemszámot tekintve a kutatásban résztvevők száma meghaladja a 100-as küszöbértéket, és beleesik a hasonló kutatási kérdések vizsgálatához használt elemszám-intervallumba (Hamari és szerzőtársai, 2016: $\mathrm{n}=174$; Ranchhod és szerzőtársai, 2014: n = 305; Geithner és Menzel, 2016: n = 47), illetve a választott módszertanok minimumkövetelményeinek is megfelel.

A módszertant több ponton lehetne fejleszteni. A kérdőív pontosításával és a megkérdezettek számának növelésével valószínüleg javulna az értékelő modell is. Érdemes lenne különböző korcsoportokat és különböző szakterületeken tanulókat is megvizsgálni, illetve hasznos lehet kontrollcsoport alkalmazása is, amire jelen kutatásban nem volt lehetőség. Kutatásunk az észlelt tanulást mérte a hallgatók megítélése alapján, a tanulási hatékonyság mérését azonban objektív szintre lehetne emelni különbözö tesztek segítségével. Mindemellett - ahogy már utaltunk rá - a kutatás kulturális vetülete is érdekes lehet. Az már most kiderült az összehasonlításból, hogy az amerikai diákok számára a kihívás jobban hozzájárult a tanuláshoz, mint az elköteleződés, az élmény. További nemzetközi öszszehasonlító vizsgálatokkal, illetve a hallgatók kulturális jellemzőire is kiterjedő adatgyüjtéssel más érdekes eredmények is feltárhatók lehetnek. 


\section{HIVATKOZÁSOK}

BEHJAT, F. - YAMINI, M. - BAgheRI, M. (2012): Blended learning: A ubiquitous learning environment for reading comprehension. International Journal of English Linguistics 2(1), 97-104. https://doi. org/10.5539/ijel.v2n1p97.

Bonk, C. J. - Graham, C. R. (2006): Handbook of blended learning: Global perspectives, local designs. San Francisco, CA: Pfeiffer Publishing.

Cerny, C. A. - Kaiser, H. F. (1977): A study of a measure of sampling adequacy for factor-analytic correlation matrices. Multivariate Behavioral Research 12(1), 43-47.

Chin, W. W. (1998): The partial least squares approach to sructural equation modeling. Chapter 10. In: Marcoulides, G. A. (1998): Modern methods for business research. London: Lawrence Erlbaum Associates, 295-336.

CsAPó, B. (2002): A tudáskoncepció változása: nemzetközi tendenciák és a hazai helyzet. Új Pedagógiai Szemle 52(2), 38-45.

Deterding, S. - Dixon, D. - Khaled, R. - Nacke, L. (2011): From Game Design Elements to Gamefulness - Defining „Gamification”. MindTrek ,11 Proceedings of the 15th International Academic MindTrek Conference: Envisioning Future Media Environments, 9-15. https://doi. org/10.1145/2181037.2181040.

DocsA, G. - SzLÁviK, P. (2015.10.13-14.): Opportunities in blended learning - how can simulations boost training programs? 10th IWKM 2015, Pozsony, Szlovákia.

Forgó, S. (2009): Az új média és az elektronikus tanulás. Új Pedagógiai Szemle 59(9), 91-96.

GARRISON, D. R. - KANUKA, H. (2004): Blended learning: Uncovering its transformative potential in higher education. The Internet and Higher Education 7(2), 95-105. https://doi.org/10.1016/j. iheduc.2004.02.001.

Geithner, S. - MenzeL, D. (2016): Effectiveness of learning through experience and reflection in a project management simulation. Simulation \& Gaming 47(2), 228-256. https://doi. org/10.1177/1046878115624312.

Greer, D. - Rowland, A. - Smith, S. (2014): Critical considerations for teaching students with disabilities in online environments. Teaching Exceptional Children 46(5), 79-91. https://doi. org/10.1177/0040059914528105.

Hair, J. F. Jr. - Hult, G. T. M. - Ringle, C. M. - Sarstedt, M. (2017): A Primer on Partial Least Squares Structural Equation Modeling (PLS-SEM). Los Angeles, USA: SAGE Publications, Inc.

Hamari, J. - Shernoff, D. J. - Rowe, E. - Coller, B. - Asbell-Clarke, J. - Edwards, T. (2016): Challenging games help students learn: An empirical study on engagement, flow and immersion in game-based learning. Computers in Human Behavior 54, 170-179. https://doi.org/10.1016/j. chb.2015.07.045

Józsa K. (2000): Az elsajátítási motiváció szerepe a kritériumorientált pedagógiában. Új Pedagógiai Szemle 50(10), 78-82.

Kolb, D. A. (1984): Experiential learning. Englewood Cliffs, NJ: Prentice Hall.

Kovács, E. (2011): Pénzügyi adatok statisztikai elemzése. Budapesti Corvinus Egyetem Pénzügyi és Számviteli Intézet, Budapest:Tanszék Kft.

Krishnan, S. (2016): Students' perceptions of learning mode in mathematics. The Malaysian Online Journal of Educational Sciences 4(2), 32-41.

Lalima, K. - Dangwal, L. (2017): Blended Learning: An Innovative Approach. Universal Journal of Educational Research 5(1), 129-136. https://doi.org/10.13189/ujer.2017.050116. 
Matute, J. - Melero, I. (2016): Game-based learning: using business simulators in the university classroom/Aprender jugando: la utilización de simuladores empresariales en el aula universitaria. Universia Business Review 51, 72.

Merkovity, N. - NemesLaki, A. (2014): eLearning fejlesztések a közszolgálatokban: Szerkesztői elöszó. Információs Társadalom 14(1), 5-8.

Motorola University (1996): Creating Mindware for the $21^{\text {st }}$ Century. Corporate University Xchange 2(3), and Alexandria: NTL Institute for Applied Behavioral Science.

Osguthorpe, R. T. - Graham C. R. (2003): Blended Learning Systems: Definitionas and directions In: Bonk, C. J. - Graham, C. R (2006): Handbook of blended learning: Global perspectives, local designs. San Francisco, CA: Pfeiffer Publishing.

PÁszToR, A. (2014): Lehetőségek és kihívások a digitális játék alapú tanulásban: egy induktív gondolkodást fejlesztő program hatásvizsgálata. Magyar Pedagógia 114(4), 281-302.

Prensky, M. (2001): Digital Natives, Digital Immigrants. On the Horizon, MCB University Press 9(5). https://doi.org/10.1108/10748120110424816.

Ranchhod, A. - GurăU, C. - Loukis, E. - Trivedi, R. (2014): Evaluating the educational effectiveness of simulation games: A value generation model. Information Sciences 264, 75-90. https://doi.org/10.1016/j.ins.2013.09.008.

Rogers, C. R. (1969): Freedom to learn. Columbus, OH: Charles E. Merrill.

Sauvé, L. - Renaud, L. - Kaufman, D. - Marquis, J. S. (2007): Distinguishing between games and simulations: A systematic review. Educational Technology \& Society 10(3), 247-256.

Snedecor, G. W. - Cochran, W. G. (1989): Statistical Methods, $8^{\text {th }}$ Edition. Iowa: Iowa State University Press.

TAO, Y. H. - Cheng, C. J. - Sun, S. Y. (2009): What influences college students to continue using business simulation games? The Taiwan experience. Computers \& Education 53(3), 929-939. https://doi.org/10.1016/j.compedu.2009.05.009. 